\title{
Biofabrication And Antitumor Activity Of Silver Nanoparticles Utilizing Novel Nostoc sp. Bahar M
}

This article was published in the following Dove Press journal:

International Journal of Nanomedicine

\author{
Mashael Mohammed Bin- \\ Meferij' $^{\prime}$ \\ Reham Samir Hamida (D) ${ }^{2}$ \\ 'Department of Biology, College of \\ Science, Princess Nourah bint \\ Abdulrahman University, Riyadh, Saudi \\ Arabia; ${ }^{2}$ Molecular Biology Unit, \\ Department of Zoology, Faculty of \\ Science, Alexandria University, \\ Alexandria, Egypt
}

Background: Over recent years, green chemistry procedures have been developed to synthesize nanoparticles in eco-friendlier and less expensive ways. These procedures use natural sources such as bacteria, fungi, yeast, plants, actinomycetes, algae, or cyanobacteria, or use biomolecules such as proteins, vitamins, or pigments instead of chemical materials to fabricate salt precursors into nanoparticles.

Methodology: In the current investigation, we developed an effective, inexpensive, nontoxic method to synthesize silver nanoparticles (SNPs) using the cellular extract of a novel strain of cyanobacterium, Nostoc sp. Bahar M. SNPs were characterized using ultravioletvisible spectroscopy, Fourier-transform infrared spectroscopy, X-ray diffraction, scanning electron microscopy, and transmission electron microscopy. The antitumor properties of the biogenic SNPs were tested against Caco-2 cells using a cell proliferation assay and inverted light microscopy.

Results: The new strain Nostoc sp. Bahar M was able to fabricate small SNPs from silver nitrate through an eco-friendly and inexpensive biosynthesis process. SNPs synthesis was accompanied by a color transformation from pale yellow to dark brown. Ultraviolet spectroscopy showed an absorption peak at $403 \mathrm{~nm}$, confirming SNPs formation. X-ray diffraction analysis indicated that the SNPs had a face-centered cubic crystalline structure. Fouriertransform infrared spectroscopy was used to identify a protein that may play an important role in SNPs biosynthesis. Scanning and transmission electron micrographs showed that the SNPs were uniformly distributed and spherical in shape, with an average diameter of 14.9 $\mathrm{nm}$. Cytotoxicity assays showed that SNPs exhibited a significant dose-dependent cytotoxic activity against human colon cancer cells with an $\mathrm{IC}_{50}$ of $150 \mu \mathrm{g} / \mathrm{mL}$.

Conclusion: Nostoc sp. Bahar M provided an eco-friendly route for fabricating SNPs, which have cytotoxic activity toward Caco-2 cells.

Keywords: cyanobacteria, nanotechnology, eco-friendly, Caco-2 cells, cytotoxic activity

\section{Introduction}

Nanotechnology and its products have improved daily life and enhanced industrial and commercial development in various sectors. ${ }^{1}$ For example, nanoparticles (NPs) have advanced the fields of bio-imaging ${ }^{2}$ and drug delivery. ${ }^{3}$ Different methods have been employed to successfully synthesize NPs, including chemical, physical, and green chemistry methods. ${ }^{4}$ The green synthesis approach of nanoparticles has been centered comparatively with other traditional routes due to its unique properties that have enhanced its industrial applications. ${ }^{5}$ Green synthesis of NPs involves using microorganisms, ${ }^{5,6}$ plants, ${ }^{7,8}$ enzymes, ${ }^{9}$ or vitamins ${ }^{10}$ to fabricate precursor materials into NPs under suitable production conditions. ${ }^{11}$ To be considered a nanomaterial or
Correspondence: Reham Samir Hamida Department of Molecular Biology, Faculty of Science, Alexandria University, Baghdad St, Moharam Bek, Alexandria, Egypt Tel +20II56298937

Email reham.hussein@alexu.edu.eg 
nanoparticle, the material or particle must have at least one dimension in the size range of 1 to $100 \mathrm{~nm} .^{12}$

Compared to chemical and physical methods, biological synthesis of NPs is reliable, cost-effective, ${ }^{13}$ cytotoxic to microorganisms, ${ }^{14}$ and cytotoxic to tumor cells. ${ }^{15}$ Furthermore, chemical synthesis of metal NPs creates highly toxic by-products, requires a high energy input, and is expensive to perform. ${ }^{16,17}$

Several organisms are able to produce metallic NPs, ${ }^{18,19}$ including yeast, bacteria, actinomycetes, fungi, plants, algae, and cyanobacteria. ${ }^{20}$ Many researchers have begun to use cyanobacteria to manufacture NPs. ${ }^{21,22}$

Cyanobacteria are a large, ancient group of photoautotrophic prokaryotes. ${ }^{23}$ They are a valuable source of many chemicals, pharmaceuticals, biofuels, pigments, and proteins. ${ }^{24}$ Nostoc is a genus of cyanobacteria that lives in various ecological habitats such as soil and hot springs. ${ }^{25}$ Nostoc is able to control its habitats by producing bio-active compounds, ${ }^{26}$ making this microorganism a valuable reservoir of diverse products. ${ }^{27}$ These compounds possess a variety of biological activities and chemical structures, and include cyclic and linear lipopeptides, fatty acids, alkaloids, and other organic chemicals. ${ }^{28}$ Many reports have mentioned the antibacterial, ${ }^{29}$ antifungal, ${ }^{30}$ and cytotoxic ${ }^{31}$ properties of these compounds. Extract from blue green algae contains several types of biomolecules that can perform reduction and capping reactions in the reduction and the stabilization processes of synthesizing NPs. ${ }^{24,32}$ Many cyanobacteria, including Anabaena sp. and Spirulina sp., have been reported to fabricate intracellular silver and gold NPs. ${ }^{21,33}$ Silver NPs (SNPs) were synthesized by whole cells of non-nitrogenfixing cyanobacteria such as Plectonema boryanum and the marine Oscillatoria willei. ${ }^{34,35}$ Recently, SNPs have been synthesized using cell extracts of Nostoc $s p$. HKAR-2 and the extracted phycobilin pigment of Nostoc $s p^{36,37}$

Biogenic SNPs have been shown to have antimicrobial, ${ }^{38}$ anticancer, ${ }^{39}$ anti-inflammatory, ${ }^{40}$ and anti-diabetic ${ }^{41}$ properties. In addition, these particles have been used to develop medicine and in various industries. ${ }^{42,43}$ They are used in water purification, ${ }^{44}$ textile engineering, ${ }^{45}$ detergents, and personal care products such as soaps ${ }^{46}$ and can act as biosensors, surgical instruments, bone cement, and surgical masks. ${ }^{47}$

Cancer is a disease with devastating effects on human health. It is estimated to be the second most common cause of death worldwide. ${ }^{48} \mathrm{New}$ compounds or methods to reduce the global effects of this disease are constantly pursued. Green NPs have been reported to prevent and inhibit the progression of malignant cells. ${ }^{49,50}$ For example, SNPs synthesized by Nostoc $s p$. HKAR-2 showed significant cytotoxicity towards the human breast cancer cell line MCF-7. ${ }^{36}$

In the present work, a novel cyanobacteria strain Nostoc sp. Bahar M was used to synthesize SNPs in an eco-friendly manner. The biofabricated SNPs were characterized and their anticancer activity toward the human colon cancer cell line Caco-2 was evaluated.

\section{Materials And Methods}

\section{Material}

SNPs were synthesized from Nostoc $s p$. extract. Silver nitrate $\left(\mathrm{AgNO}_{3}\right)$ and cell culture materials were purchased from Sigma-Aldrich (St. Louis, MO, USA). Colon carcinoma cells (Caco-2) were purchased from the Medical Research Institute (Alexandria, Egypt).

\section{Methods}

\section{Sample Collection And Purification}

Cyanobacteria isolates were collected from soil in Alexandria, Egypt and kept sterile until reaching the laboratory. Samples were purified following the method developed by Bolch et al. ${ }^{51}$ Briefly, samples were diluted 15-fold using sterile BG11 media $(\mathrm{pH}=7)$. Drops of the diluted samples were spread on BG11 agar plates and incubated at typical temperature and under light intensity of $2000 \pm 200$ lux provided by a cool white fluorescent lamp. An inverted light microscope was used to identify plates containing purified colonies suitable for large scale growth. Colonies were inoculated into $500 \mathrm{~mL}$ sterile flasks containing aqueous modified BG11 media without any nitrogen source and incubated with agitation for 15 days at room temperature.

\section{Identification Of Nostoc sp Morphological Examination}

Aliquots of the cyanobacteria were examined using an inverted light microscope (Optika, Ponteranica BG, Italy). Taxonomic identification of the isolates was based on their morphology. ${ }^{52}$

\section{Molecular Identification}

DNA extraction. DNA was extracted from the microorganisms following the method of Singh et al. ${ }^{53}$ Purified DNA was analyzed by gel electrophoresis (ReadyAgarose ${ }^{\mathrm{TM}}$ Precast Gel System Bio-Rad Laboratories, Inc., California, USA) to check for DNA contamination or fragmentation. 
Polymerase chain reaction amplification and Sanger's dideoxynucleotide sequencing of I6S rRNA. DNA concentration was measured with a spectrophotometer (Jenway, Staffordshire, OSA, UK). DNA was amplified by polymerase chain reaction (PCR) (Multigene Optimax, Labnet International, Inc., Edison, NJ, USA) using suitable primers; the forward primer was 5'-AGAGTTTGATCMTGGCTCAG$3^{\prime}$ (position 8 in the 16S rRNA gene according to $E$. coli numbering) and the reverse primer was 3'TACGGYAC CTTGTTACGACTT-5' (position 1514 in the 16S rRNA gene according to $E$. coli numbering). After gel electrophoresis to confirm the success of the previous steps, the amplified DNA was stored in nuclease-free water and sequenced using an ABI 3730 DNA sequencer (Thermo Fisher Scientific, Waltham, MA, USA).

Phylogenetic analysis. Genetic data were analyzed using a BLAST search (http://www.ncbi.nim.nih.gov/) to compare this sequence with other cyanobacterial $16 \mathrm{~S}$ rRNA sequences in GenBank. This phylogenetic analysis was performed to identify the relation between Nostoc $s p$. and the closely related cyanobacteria. Multi-sequence alignment was performed using Clustal W (https://www.genome.jp/tools-bin/clustalw) and the phylogenetic tree was created using MEGA software version 4.0.2.

\section{Preparation Of Cyanobacteria Extract}

After two weeks of growth, the purified Nostoc sp. culture was harvested and washed by centrifugation at $4000 \mathrm{rpm}$. The biomass was freeze-dried and ground using a mortar and pestle, and $20 \mathrm{mg}$ of the resulting fine powder was suspended in $20 \mathrm{~mL}$ of sterile water. This mixture was incubated at $30^{\circ} \mathrm{C}$ for $24 \mathrm{~h}$, then filtered with Whatman filter paper no.1 (Camlab, Cambridge, United Kingdom).

\section{SNPs Fabrication By Cyanobacteria}

For SNPs synthesis, $10 \mathrm{~mL}$ of the filtrate was mixed with $90 \mathrm{~mL}$ of $1 \mathrm{mM} \mathrm{AgNO}_{3}$ solution at room temperature for $24 \mathrm{~h}$ in the dark. Another sterile flask of $\mathrm{AgNO}_{3}$ solution without cyanobacteria filtrate was prepared as a positive control. After $24 \mathrm{~h}$, the mixtures were centrifuged at $4{ }^{\circ} \mathrm{C}$ for $30 \mathrm{~min}$ at $10,000 \mathrm{rpm}$. The resultant pellet was washed at least three times to eliminate uncapping nanomaterial and spread on sterile plates to dry at $40^{\circ} \mathrm{C}$ for $24 \mathrm{~h}$. Dried powder was collected for further study.

\section{Physicochemical Analysis Of The Biogenic SNPs UV-Visible Spectroscopy}

After the biofabrication process, aliquots $(1 \mathrm{~mL})$ of the SNPs mixture were taken for UV monitoring using a UV spectrophotometer (UV1800 PC spectrophotometer, Shimadzu, Japan) from 300 to $700 \mathrm{~nm}$.

\section{X-Ray Diffraction}

X-ray diffraction (XRD) (X-ray 7000, Shimadzu, Japan) was performed to confirm the crystalline nature of the biogenic SNPs. Biogenic SNPs were drop-coated onto a silica plate with intermittent drying to obtain a thick coat of SNPs for XRD. Diffraction patterns were obtained at 30 $\mathrm{kV}$ and $30 \mathrm{~mA}$ in $\mathrm{Cu}, \mathrm{K}$-alpha radiation, with a Bragg angle $(2 \theta)$ range of $0^{\circ}$ to $80^{\circ}$ and scan speed $4 \mathrm{deg} / \mathrm{min}$.

\section{Fourier-Transform Infrared Spectroscopy}

Fourier-transform infrared (FTIR) spectroscopy was used to detect the biomolecules in the extracts responsible for NPs synthesis. Samples were prepared by diluting biogenic SNPs powders 1:100 in potassium bromide. Diffuse reflectance FTIR (Shimadzu, Japan) was measured from 400 to $4000 \mathrm{~cm}^{-1}$ at a resolution of $4 \mathrm{~cm}^{-1}$. FTIR results were compared to a reference chart to identify functional groups in the target sample.

\section{Scanning Electron Microscopy}

Scanning electron microscopy (SEM) (Jeol, Tokyo, Japan) was used to characterize SNPs morphology. Briefly, a small amount of an aqueous solution of SNPs was placed onto a carbon coated copper grid, and extra solution was removed from the grid with blotting paper. The thin film on the grid was dried under a mercury lamp for $5 \mathrm{~min}$ before examination.

\section{Transmission Electron Microscopy}

Transmission electron microscopy (TEM) images were obtained to examine the shape and size of the biosynthesized SNPs. TEM (Jeol, Tokyo, Japan) was performed at an accelerating voltage of $200 \mathrm{kV}$. After sonication for 5 min, a drop of SNPs solution was placed on a carbon coated copper grid and dried under an infrared lamp before TEM evaluation.

\section{Cell Culture}

In brief, the Caco- 2 cell line was maintained in Dulbecco's modified Eagle's Minimum Essential Medium with 10\% fetal bovine serum and $50 \mathrm{IU} / \mathrm{mL}$ penicillin and streptomycin. Cells were allowed to grow in a humidified atmosphere containing $5 \% \mathrm{CO}_{2}$ and $95 \%$ air at $37^{\circ} \mathrm{C}$. Confluent cells were passaged with trypsin-EDTA. 


\section{Cell Proliferation Assay}

The cytotoxicity of biogenic SNPs synthesized by Nostoc $s p$. was evaluated after $24 \mathrm{~h}$ of incubation against Caco-2 cells with the MTT tetrazolium reduction assay. Cells were seeded in 96-well plates with $7 \times 10^{3}$ cells/well. SNPs were filtered through $0.22 \mu \mathrm{m}$ sterile filters. After achieving cell culture confluence, cells were subjected to different SNPs concentrations from $31.25 \mu \mathrm{g} / \mathrm{mL}$ to $1000 \mu \mathrm{g} /$ $\mathrm{mL}$. After $24 \mathrm{~h}$ the medium was discarded and replaced with $100 \mu \mathrm{L}$ of fresh culture medium, and $10 \mu \mathrm{L}$ of 12 mM MTT stock solution was added to each well. As a negative control, $10 \mu \mathrm{L}$ of $12 \mathrm{mM}$ MTT stock solution was added to $100 \mu \mathrm{L}$ of the medium alone. Cells were incubated for $4 \mathrm{~h}$ at $37^{\circ} \mathrm{C}$ and $100 \mu \mathrm{L}$ DMSO was added to each well with thorough mixing to dissolve the formazan crystal. The absorbance intensity was measured at $570 \mathrm{~nm}$ by enzyme-linked immunosorbent assay (ELISA) (BioRad Laboratories, Hercules, CA, USA). In ELISA, absorbance is directly related to the number of viable cells, allowing the half-maximal growth inhibitory concentration $\left(\mathrm{IC}_{50}\right)$ to be estimated.

\section{Morphological Observation Of Cells}

Cell morphology was examined before and after SNPs treatment using an inverted light microscope (Optika, Ponteranica BG, Italy) at 400X magnification. Cells were seeded onto 12-well plates to be sub-confluent, treated with biogenic SNPs at $\mathrm{IC}_{50}$ and $\mathrm{IC}_{25}(150 \mu \mathrm{g} / \mathrm{mL}$ and 75 $\mu \mathrm{g} / \mathrm{mL}$, respectively), and incubated for $24 \mathrm{~h}$ at $37^{\circ} \mathrm{C}$. Untreated control cells were also incubated for $24 \mathrm{~h}$.

\section{Statistical Analysis}

All results are presented as mean values of three independent replicates (mean $\pm \mathrm{SD}$ ) and statistical analyses were done by one-way ANOVA analysis of variance using Prism 6 software (GraphPad Software Inc., La Jolla, CA, USA). Values were considered statistically significant at $\mathrm{P}$ $<0.01$ and $\mathrm{P}<0.001$. Origin8 (OriginLab Corporation, Northampton, MA, USA) and ImageJ (National Institutes of Health, Bethesda, MD, USA) were also used to analyze NPs.

\section{Results And Discussion}

Inverted light micrographs of Nostoc sp. showed barrel-shaped trichomes (Figure 1A). In addition, several spherical cells enveloped by a sheath were observed, and these cells may be coccoid cells (Figure 1B). These data are in agreement with data reported by
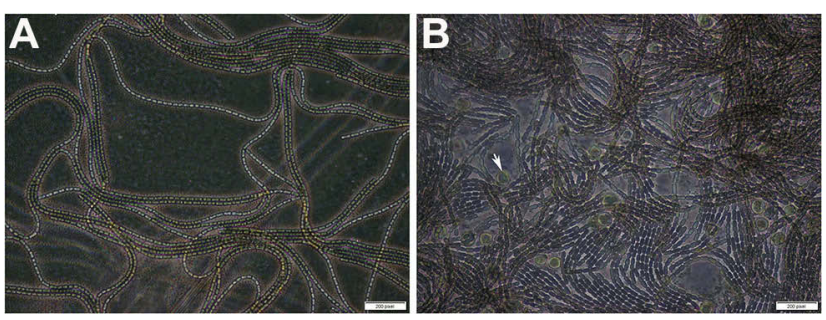

Figure I Inverted light micrographs of Nostoc Bahar M strain.

Notes: (A) Barrel-shaped Nostoc trichomes. (B) Coccoid cells (arrow) surrounded by a sheath.

Nowruzi et $\mathrm{al}^{25}$ who identified and studied the toxicity of Nostoc sp.

In the current study, whole genomic DNA was extracted, purified, and used as a PCR template. Agarose gel electrophoresis of the resultant amplicon $(1.5 \mathrm{~kb})$ of the selected isolate is shown in (Figure 2). The phylogeny of the selected strain was analyzed using a multi-sequence alignment program, and the results were used to create a phylogenetic tree (Figure 3). The AM1 strain was 97\% similar to Nostoc sp. Bahar M. ${ }^{25}$ Sequence data for the selected isolate was deposited in GenBank as MN423202.

The primary indicator of SNPs synthesis was the color change from greenish-brown to pale yellow, gradually

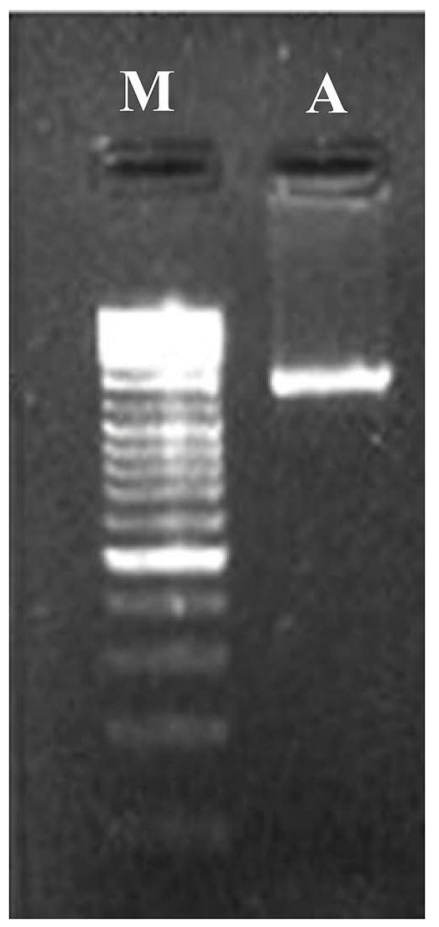

Figure 2 Electrophoresis of the extracted genomic DNA in a $1 \%$ agarose gel. Notes: (A) 16S rDNA amplified by PCR from genomic DNA of Nostoc. (M) Molecular marker 1500 bp.

Abbreviation: PCR, polymerase chain reaction. 


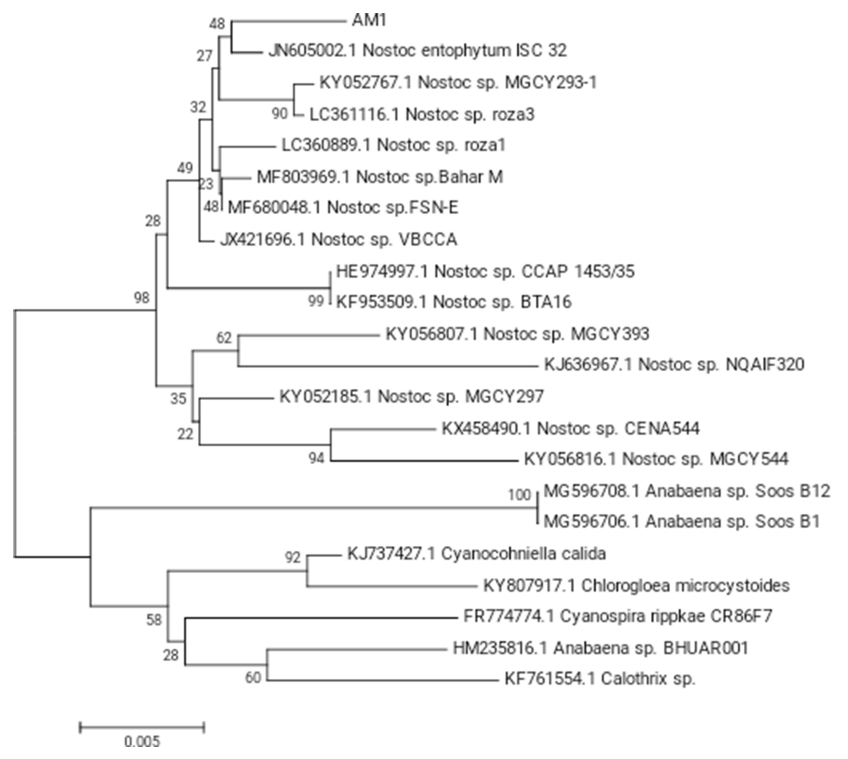

Figure 3 The phylogenetic tree of Nostoc sp. based on partial sequencing of 165 rRNA.

becoming dark brown with increased incubation time. This color change is due to the excitation of surface plasmon resonance (SPR). The biogenic SNPs had a peak at 403 $\mathrm{nm}$ (Figure 4), indicating SNPs fabrication from bulk $\mathrm{AgNO}_{3}$. This finding agrees with Ahmed et al, who reported that biogenic SNPs synthesized by Nostoc $s p$. showed SPR peaks centered at $400-402 \mathrm{~nm}^{54}$ On the other hand, other publications that used Nostoc linckia, and Nostoc commune to synthesize SNPs reported SPR peaks at 415 and $435 \mathrm{~nm}$, respectively. ${ }^{55,56}$ Furthermore, SNPs produced from the reaction of phycoerythrin and an aqueous $\mathrm{AgNO}_{3}$ solution had a distinct peak at $430 \mathrm{~nm} .{ }^{37}$

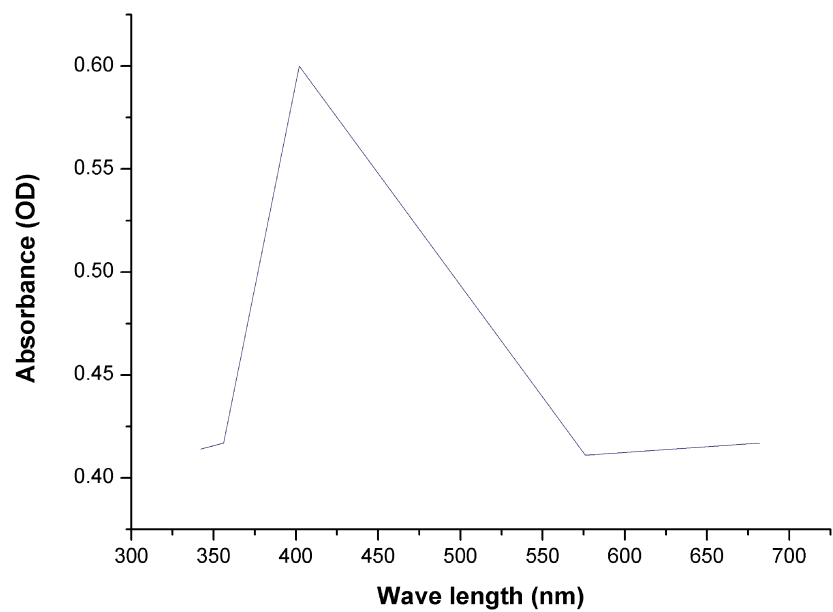

Figure 4 UV-vis absorption spectra of biogenic SNPs synthesized by Nostoc sp. Note: The plasmon resonance of SNPs at $403 \mathrm{~nm}$.

Abbreviations: UV-vis, ultraviolet-visible; SNPs, silver nanoparticles.
The different SPR values may be related to the different strains of Nostoc sp. and different biomolecules involved in producing SNPs.

The XRD pattern of SNPs synthesized by Nostoc $s p$. Bahar M showed four intense peaks (Figure 5) with $2 \Theta$ values of $38.2,45.3,67.44$, and $75.25^{\circ}$, related to the silver (111), (200), (220), and (300) planes, respectively. Comparisons of each spectrum with standards from the Joint Committee on Powder Diffraction Standards library helped determine that the SNPs were crystalline. The current results are similar to the $2 \Theta$ values of SNPs fabricated by Streptomyces $s p$. and Coleus aromaticus, which

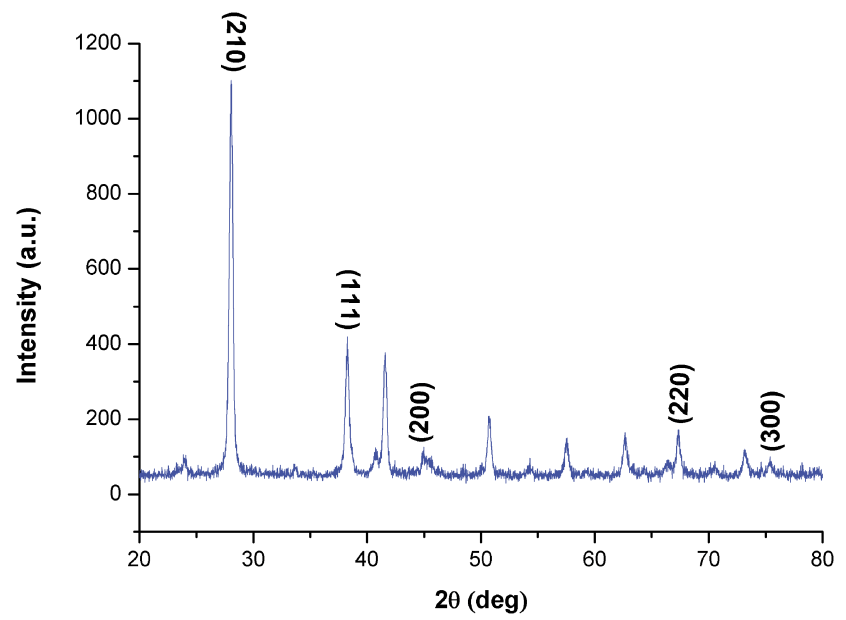

Figure 5 XRD pattern of biogenic SNPs synthesized by Nostoc sp. Note: Four peaks at $3.5 \mathrm{KeV}$ ranging from $0^{\circ}$ to $80^{\circ}$ at $2 \Theta$ values for SNPs. Abbreviations: XRD, x-ray diffraction; SNPs, silver nanoparticles. 
were reported to be $45.3,27.51,75.2$, and $67.44^{\circ} .{ }^{57,58} \mathrm{~A}$ sharp peak at $2 \Theta$ of $28^{\circ}$ was recorded by XRD. This peak might be related to the crystallization of biogenic groups on the NP surface. ${ }^{59}$ XRD provides information about the shape, size, and orientation of the SNPs. ${ }^{37}$ SNP crystal size, calculated from the highest intensive signal (111) using the Scherrer equation, ${ }^{60} \mathrm{D}=0.9 \kappa / \beta \cos \theta$, was found to be $3.8 \mathrm{~nm}$. The interplanar distance of crystal particles (d), calculated using Bragg's law, $d=n K / 2$ Sin $\theta$, was found to be $0.26 \mathrm{~nm}$ which is corresponding to the (111) plane of metallic silver.

FTIR analysis distinctly showed the spectral wavenumbers of the bioactive groups surrounding the biogenic SNPs that were responsible for SNPs fabrication and stabilization. FTIR spectroscopy of reduced SNPs (Figure 6) showed 14 absorption peaks, including peaks at $1119.01 \mathrm{~cm}^{-1}$ (C-O secondary alcohol), $1397.07 \mathrm{~cm}^{-1}$ (O-H carboxylic acid), $1632.35 \mathrm{~cm}^{-1}$ (N-H stretching amine $), 1777.14 \mathrm{~cm}^{-1}(\mathrm{C}=\mathrm{O}$ stretching anhydride or vinyl/phenyl ester), $2114.44 \mathrm{~cm}^{-1}(\mathrm{~N}=\mathrm{C}=\mathrm{S}$ stretching isothiocyanate), $2946.98 \mathrm{~cm}^{-1}$ (stretching O-H carboxylic acid or $\mathrm{N}-\mathrm{H}$ amine salt), $3460.32 \mathrm{~cm}^{-1}(\mathrm{O}-\mathrm{H}$ stretching alcohol), and $842.59 \mathrm{~cm}^{-1}$ (stretching alkene $\mathrm{C}=\mathrm{C}$ ). Based on the FTIR results, the aromatic compound may represent the reducing ligand of the SNPs during the synthesis process. Moreover, the existence of amine groups on the NP surface was supported by FTIR analysis, indicating that proteins may act as capping ligands and prevent agglomeration of reduced SNPs. ${ }^{55,61}$ Gole et al ${ }^{62}$ explained that proteins can bind NPs through negatively charged carboxylate groups, cysteine residues, or free amine groups in the proteins.

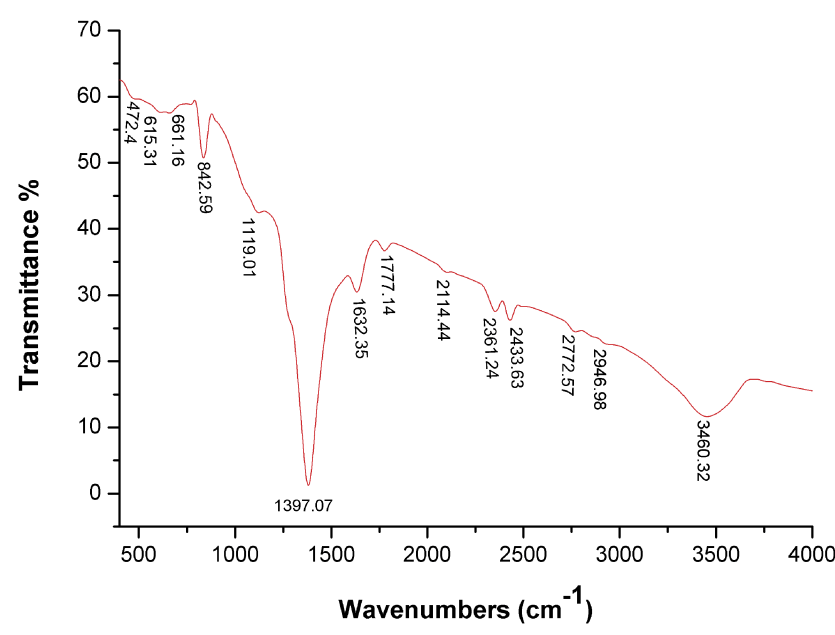

Figure 6 FTIR spectra of biogenic SNPs.

Abbreviations: FTIR, Fourier-transform infrared; SNPs, silver nanoparticles.
Sastry et $\mathrm{al}^{63}$ emphasized that functional groups such as $-\mathrm{C}-\mathrm{O}-\mathrm{C}-,-\mathrm{C}=\mathrm{C}-$ and $-\mathrm{C}-\mathrm{O}-$ that exist in heterocyclic compounds like proteins play important roles in stabilizing and reducing NPs. Although the exact mechanism by which biomolecules in the cell extract are involved in NP synthesis is poorly understood, El-Batal et al ${ }^{64}$ revealed that an NADH-dependent reductase was critical in SNPs biosynthesis. El-Naggar et $\mathrm{al}^{61}$ also stated that biomolecules (eg proteins, enzymes, amino acids, carbohydrates, photosynthetic pigments, carotenoids, and vitamins) present in cell extracts have been implicated in the reduction of $\mathrm{Ag}^{+}$ions.

SEM micrographs revealed that SNPs fabricated by Nostoc sp. had a spherical shape and ranged from 30 to 50 $\mathrm{nm}$, with some SNPs forming larger agglomerates (Figure 7). NPs agglomeration may be due to the aqueous extract of Nostoc sp. around the SNPs. ${ }^{65}$ Sonker et al ${ }^{36}$ used SEM imaging to determine that the size of silver synthesized by Nostoc sp. HKAR-2 ranged from 51 to $100 \mathrm{~nm}$, while Anderson et al $^{66}$ reported that the hydrodynamic diameter of SNPs synthesized by seaweed extract was between 20 and $95 \mathrm{~nm}$. Moreover, Al Rashid et al mentioned that SEM micrograph of biosynthesized SNPs by Momordica charantia fruit extract showed that SNPs were spherical and have diameter range from 78.5 to $100 \mathrm{~nm} .{ }^{67} \mathrm{It}$ is noteworthy that the Bahar $\mathrm{M}$ strain can reduce $\mathrm{AgNO}_{3}$ into smaller size SNPs with less size range, a property that highlights the possible applications of SNPs synthesized by Nostoc sp. Bahar $\mathrm{M}$ in diverse fields.

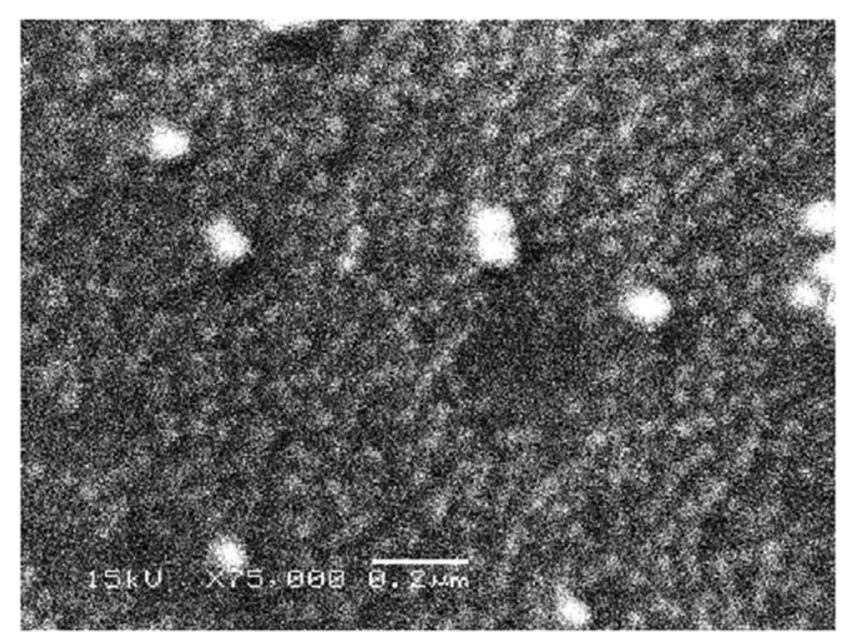

Figure 7 SEM examination of SNPs.

Notes: SEM image showing the spherical shape of SNPs, with some SNPs aggregations. Scale bar, $0.2 \mu \mathrm{m}$.

Abbreviations: SEM, scanning electron microscope; SNPs, silver nanoparticles. 

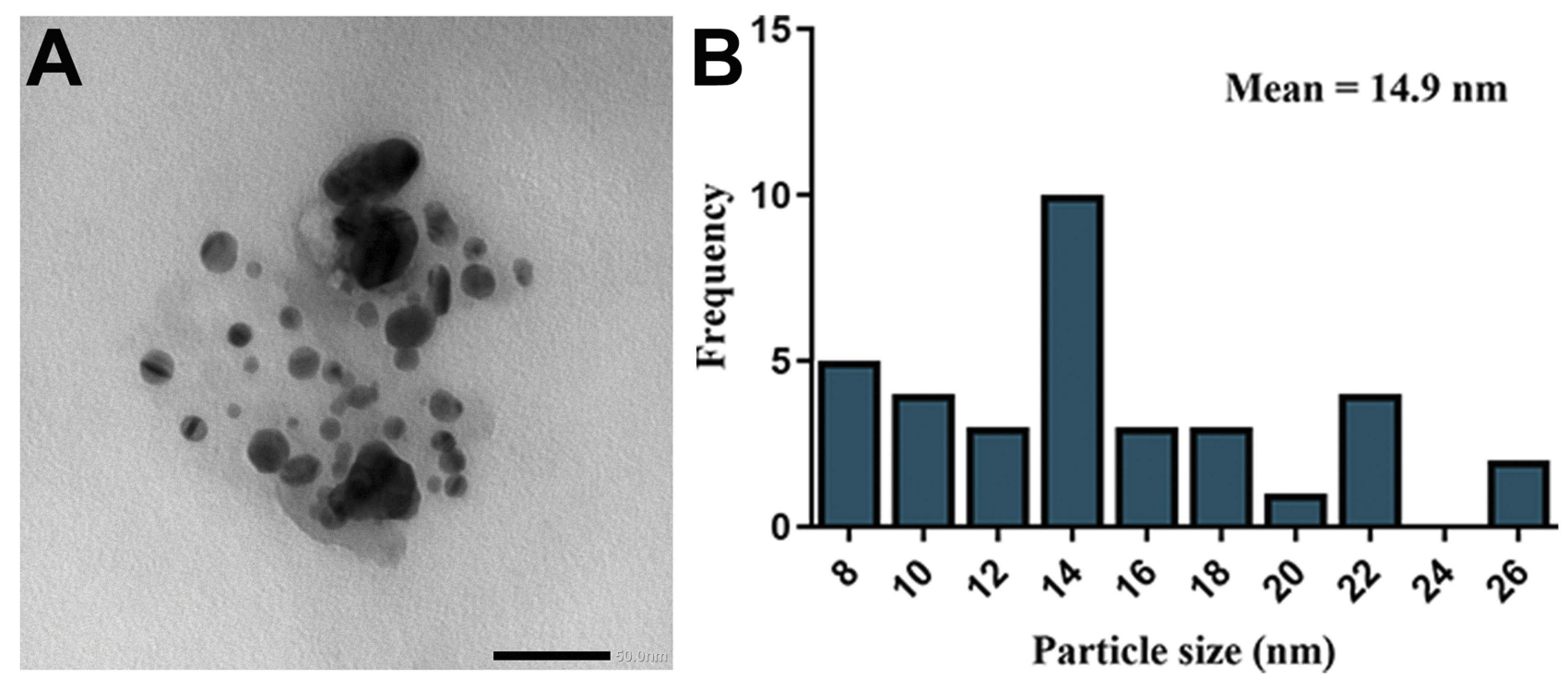

Figure 8 TEM examination and size distribution of SNPs.

Notes: (A) TEM micrograph exhibiting the spherical shape of SNPs with size range of 8.5 to $26.44 \mathrm{~nm}$. Scale bar, $50 \mathrm{~nm}$. (B) SNPs size distribution from TEM analysis, with average size of $14.9 \mathrm{~nm}$.

Abbreviations: TEM, transmission electron microscope; SNPs, silver nanoparticles.

TEM was employed to characterize the size and shape of synthesized SNPs. TEM images revealed that biogenic SNPs had a spherical shape (Figure 8A), consistent with the shape of an SPR band in the UV-visible (UV-vis) spectrum. Moreover, the NP size ranged from 8.5 to $26.44 \mathrm{~nm}$, with an average particle size of 14.9 $\mathrm{nm}$ (Figure 8B). ${ }^{37}$ Also, TEM micrograph showed that the inter particle distance was equal to $31.4 \mathrm{~nm}$. Morsy et $\mathrm{al}^{55}$ reported that the SNPs fabricated using cellular extract of Nostoc commune were spherical and had sizes from 15 to $51 \mathrm{~nm}$. The current results compared with data from Morsy et $\mathrm{al}^{55}$ demonstrate the potential of the Nostoc Bahar M strain to fabricate smaller SNPs. Creating particles have smaller nano-size scale will encourage researchers to use various cyanobacteria for biosynthesis of different NPs.

To the best of our knowledge, this is the first report regarding the anticancer activity of SNPs biosynthesized using the cell extract of Nostoc sp. Bahar M on Caco-2 cells. SNPs suppressed cell proliferation in a dose-dependent manner compared with untreated cells (Figure 9A). The $\mathrm{IC}_{50}$ of SNPs was $150 \mu \mathrm{g} / \mathrm{mL}$ (Figure 9B). Martins et $\mathrm{al}^{68}$ tested the influence of a polyelectrolyte complex containing SNPs against Caco-2 cells and healthy African green monkey cells (VERO cells) and found that the SNPs exhibited cytotoxic effects on Caco-2 cells, but not VERO cells, at concentrations above $100 \mu \mathrm{g} / \mathrm{mL}$. Song et $\mathrm{al}^{69}$ reported that SNPs showed slight cytotoxic activity against
Caco-2 cells at 10, 25, 50, 100, and $200 \mu \mathrm{g} / \mathrm{mL}$. Our results indicate that SNPs synthesized using Nostoc $s p$. Bahar $\mathrm{M}$ are more potent antitumor agents against Caco2 cells than the chemically synthesized SNPs studied by Martins et $\mathrm{al}^{68}$ and Song et al. ${ }^{69}$

Control cells showed a normal distribution, with a confluent monolayer of cells attached to the plate and a small distance between cells (Figure 10A). Caco-2 cells treated with SNPs at $\mathrm{IC}_{25}$ exhibited moderate morphological changes, including cell detachment, shrinkage, and clustering, with restricted cell spreading (Figure 10B). However, Caco-2 cells treated with SNPs at $\mathrm{IC}_{50}$ exhibited more drastic changes, including cell rounding and features characteristic of apoptotic cell death, in a dosedependent manner (Figure 10C). SNP-treated colon cells exhibited morphological changes such as shrinkage, irregular shape and plasma membrane repture. ${ }^{69,70}$ Likewise, Böhmert et al used inverted light microscopy to examine Caco-2 cells after SNP treatment and reported altered cell shape and cell adhesion capacity compared to control cells. ${ }^{71}$

The MTT data and cytomorphological observations indicate that the cytotoxic effect of SNPs toward Caco-2 cells may result from an interaction of SNPs with different organelles such as the mitochondria, nucleus, or endoplasmic reticulum, or through direct interaction with biomolecules such as DNA, enzymes, or proteins. This interaction may affect cell membrane integrity, lactate dehydrogenase 


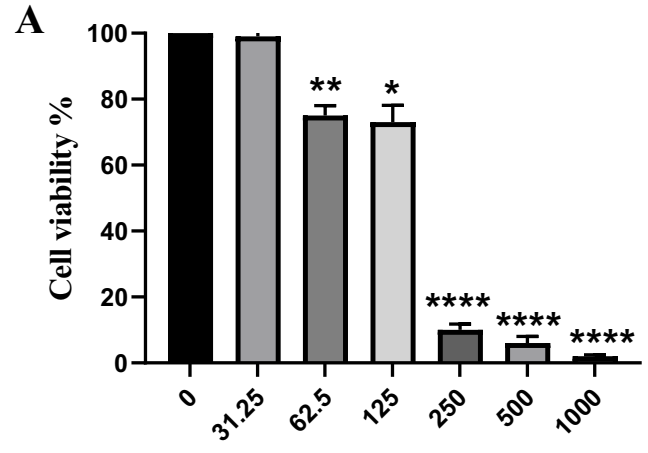

\section{Concentrations of SNPs $(\mu \mathrm{g} / \mathrm{ml})$}

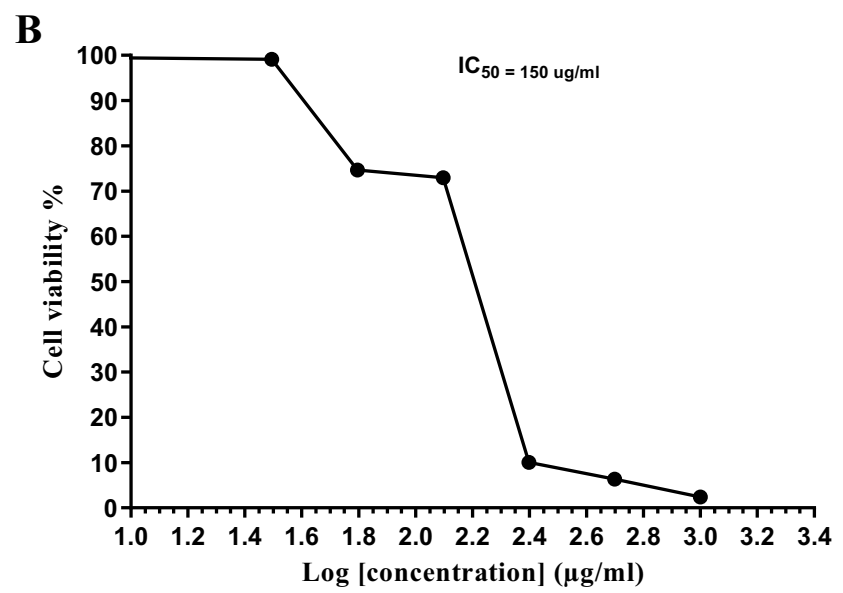

Figure 9 Dose-dependent growth inhibition of Caco-2 cells by SNPs. Notes: (A) Antiproliferative effect of SNPs synthesized by Nostoc sp. against Caco2 cell line expressed as percentage cell viability. (B) Caco-2 cell viability percentage and the log concentration at which cell viability is reduced to $50 \%$. Data from at least three independent experiments performed in at least triplicate are presented as mean $\pm \mathrm{SD} ; P$ value was calculated versus control cells: $* P<0.05 ; * * P<0.0$ I and ***** $P<0.001$.

Abbreviations: SNPs, silver nanoparticles; SD, standard deviation.

levels, and mitochondrial permeability, causing oxidative stress and cell death. ${ }^{37}$

\section{Conclusion}

Nanomaterials represent an alternative strategy for cancer treatment to overcome multidrug resistance and several drawbacks of traditional therapies. Problems with nanomaterial production, including toxic by-products of their synthesis, limit their applications. A green chemistry approach to NPs synthesis offers a solution to safely produce NPs. The current study demonstrated the eco-friendly synthesis of SNPs using cellular extract from a new strain of cyanobacteria, Nostoc sp. Bahar M. These SNPs are spherical with diameters of 8.5 to $26.44 \mathrm{~nm}$. The biogenic SNPs had potent antitumor activity against Caco- 2 cells, and cytotoxicity data showed that it would be possible to utilize SNPs as
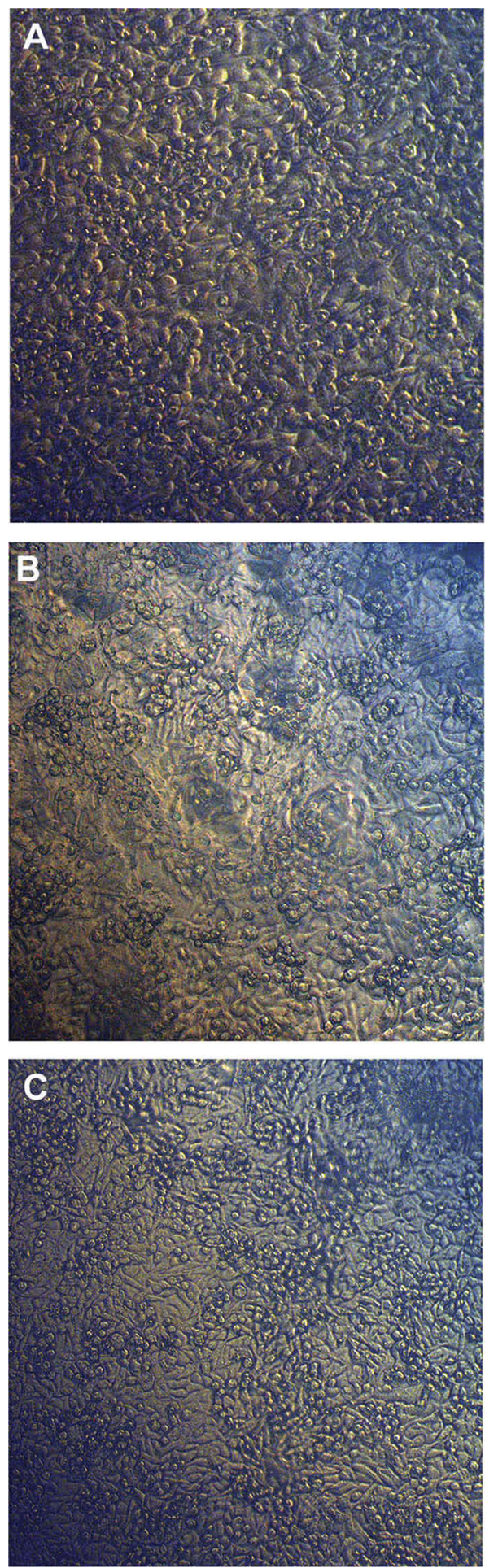

Figure 10 Inverted light micrographs of Caco-2 cells.

Notes: Morphological changes in Caco-2 cells before and after being treated with SNPs. (A) Control, (B) Caco-2 cells treated with $\mathrm{IC}_{25}$ SNPs $(75 \mu \mathrm{g} / \mathrm{mL})$, (C) Caco2 cells treated with $I_{50}$ SNPs $(150 \mu \mathrm{g} / \mathrm{mL})$.

Abbreviation: SNPs, silver nanoparticles.

an antitumor agent against cancerous cells. Further research is needed to understand the mode of action of these NPs as anticancer agents. 


\section{Ethics Approval And Informed Consent}

The current study followed the Research Ethical Committee guidelines published by the National Health and Medical Research Council and the Ministry of Health and Population in Egypt. The Department of Zoology (Science Faculty, Alexandria University) and the Department of Cancer Management and Research (Medical Research Institute, Alexandria University) granted permission for this work.

\section{Abbreviations}

NPs, Nanoparticles; SNPs, Silver nanoparticles; $\mathrm{AgNO}_{3}$, Silver nitrate; PCR, Polymerase chain reaction; $\mathrm{nm}$, Nanometer; min, Minute; $\mu \mathrm{L}$, Microliter; mg, Milligram; $\mathrm{mL}$, Milliliter; $\mu \mathrm{g}$, Microgram; mM, Millimolar; h, Hour; $\mathrm{cm}^{-1}$, Inverse centimeter; rpm, Revolutions per minute; SEM, Scanning electron microscope; TEM, Transmission electron microscope; DLS, Dynamic light scattering; FTIR, Fourier-transform infrared spectroscopy; XRD, X-ray diffraction; kV, Kilovolt; kb, Kilobase; SPR, Surface plasmon resonance; ELISA, Enzyme-linked immunosorbent assay; UV-vis, Ultraviolet-visible spectroscopy.

\section{Data Availability}

The data supporting this article are available in Figures 1-10. The data sets analyzed in the present study are available from the corresponding author on reasonable request.

\section{Acknowledgments}

This research was funded by the Deanship of Scientific Research at Princess Nourah bint Abdulrahman University through the Fast-track Research Funding Program.

\section{Author Contributions}

All authors contributed to data analysis and drafting or revising the article. All authors gave final approval of the published article and are accountable for all aspects of the work.

\section{Disclosure}

This research was included in a request for patent 119410021 from King Abdulaziz City for Science and Technology, submitted 5/9/2019, titled "Biosynthesis of silver nanoparticles as anticancer agents" Patents.kacst. edu.sa. The authors report no other conflicts of interest in this work.

\section{References}

1. Lin Z, Xu Y, Zhen Z, et al. Application and reactivation of magnetic nanoparticles in Microcystis aeruginosa harvesting. Bioresour Technol. 2015;190:82-88. doi:10.1016/j.biortech.2015.04.068

2. Huerta-Aguilar CA, Ramírez-Guzmán B, Thangarasu P, Narayanan J, Singh N. Simultaneous recognition of cysteine and cytosine using thiophene-based organic nanoparticles decorated with Au NPs and bio-imaging of cells. Photochem Photobiol Sci. 2019;18:1761-1773. doi:10.1039/C9PP00060G

3. Rizvi SA, Saleh AM. Applications of nanoparticle systems in drug delivery technology. Saudi Pharm J. 2018;26(1):64-70. doi:10.1016/ j.jsps.2017.10.012

4. Gour A, Jain NK. Advances in green synthesis of nanoparticles. Artif Cells Nanomed Biotechnol. 2019;47(1):844-851. doi:10.1080/2169 1401.2019.1577878

5. Pugazhendhi A, Prabakar D, Jacob JM, Karuppusamy I, Saratale RG. Synthesis and characterization of silver nanoparticles using Gelidium amansii and its antimicrobial property against various pathogenic bacteria. Microb Pathog. 2018;114:41-45. doi:10.1016/j.micpath.2017.11.013

6. Otari S, Patil R, Ghosh S, Thorat N, Pawar S. Intracellular synthesis of silver nanoparticle by actinobacteria and its antimicrobial activity. Spectrochim Acta Part A. 2015;136:1175-1180. doi:10.1016/j. saa.2014.10.003

7. Srinivasan M, Venkatesan M, Arumugam V, et al. Green synthesis and characterization of titanium dioxide nanoparticles (TiO2 NPs) using Sesbania grandiflora and evaluation of toxicity in zebrafish embryos. Process Biochem. 2019;80:197-202. doi:10.1016/j.procbio.2019.02.010

8. Vasantharaj S, Sathiyavimal S, Saravanan M, et al. Synthesis of ecofriendly copper oxide nanoparticles for fabrication over textile fabrics: characterization of antibacterial activity and dye degradation potential. J Photochem Photobiol B. 2019;191:143-149. doi:10.1016/ j.jphotobiol.2018.12.026

9. Mishra A, Sardar M. Alpha-amylase mediated synthesis of silver nanoparticles. Sci Adv Mater. 2012;4(1):143-146. doi:10.1166/ sam.2012.1263

10. Shao Y, Wu C, Wu T, et al. Green synthesis of sodium alginate-silver nanoparticles and their antibacterial activity. Int J Biol Macromol. 2018;111:1281-1292. doi:10.1016/j.ijbiomac.2018.01.012

11. Hulkoti NI, Taranath T. Biosynthesis of nanoparticles using microbes - a review. Colloids Surf B. 2014;121:474-483. doi:10.1016/j.colsurfb. 2014.05.027

12. Zarina A, Nanda A. Green approach for synthesis of silver nanoparticles from marine Streptomyces-MS 26 and their antibiotic efficacy. J Pharm Sci Res. 2014;6(10):321-327.

13. Shanmuganathan R, Karuppusamy I, Saravanan M, et al. Synthesis of Silver nanoparticles and their biomedical applications-A comprehensive review. Curr Pharm Des. 2019;25(11):2650-2660. doi:10.2174/ 1381612825666190708185506

14. Kubyshkin A, Chegodar D, Katsev A, Petrosyan A, Krivorutchenko Y, Postnikova O. Antimicrobial effects of silver nanoparticles stabilized in solution by sodium alginate. Biochem Mol Biol J. 2016;2 (2):1-16. doi:10.21767/2471-8084.100022

15. Patra JK, Das G, Shin H-S. Facile green biosynthesis of silver nanoparticles using Pisum sativum L. outer peel aqueous extract and its antidiabetic, cytotoxicity, antioxidant, and antibacterial activity. Int $J$ Nanomedicine. 2019;14:6679-6690. doi:10.2147/IJN.S212614

16. Shankar SS, Rai A, Ahmad A, Sastry M. Rapid synthesis of Au, Ag, and bimetallic $\mathrm{Au}$ core-ag shell nanoparticles using Neem (Azadirachta indica) leaf broth. $J$ Colloid Interface Sci. 2004;275 (2):496-502. doi:10.1016/j.jcis.2004.03.003

17. Vilchis-Nestor AR, Sánchez-Mendieta V, Camacho-López MA, Gómez-Espinosa RM, Camacho-López MA, Arenas-Alatorre JA. Solventless synthesis and optical properties of $\mathrm{Au}$ and $\mathrm{Ag}$ nanoparticles using Camellia sinensis extract. Mater Lett. 2008;62(1718):3103-3105. doi:10.1016/j.matlet.2008.01.138 
18. Buttacavoli M, Albanese NN, Di Cara G, et al. Anticancer activity of biogenerated silver nanoparticles: an integrated proteomic investigation. Oncotarget. 2018;9(11):9685-9705. doi:10.18632/oncotarget.23859

19. Shahzad A, Saeed H, Iqtedar M, et al. Size-controlled production of silver nanoparticles by Aspergillus fumigatus BTCB10: likely antibacterial and cytotoxic effects. J Nanomater. 2019;2019:1-14. doi:10.1155/ 2019/5168698

20. Asmathunisha N, Kathiresan K. A review on biosynthesis of nanoparticles by marine organisms. Colloids Surf B. 2013;103:283-287. doi:10.1016/j.colsurfb.2012.10.030

21. Singh G, Babele PK, Shahi SK, Sinha RP, Tyagi MB, Kumar A. Green synthesis of silver nanoparticles using cell extracts of Anabaena doliolum and screening of its antibacterial and antitumor activity. J Microbiol Biotechnol. 2014;24(10):1354-1367. doi:10.4014/jmb.1405.05003

22. Sharma A, Sharma S, Sharma K, et al. Algae as crucial organisms in advancing nanotechnology: a systematic review. J Appl Phycol. 2016;28(3):1759-1774. doi:10.1007/s10811-015-0715-1

23. Rippka R, Deruelles J, Waterbury JB, Herdman M, Stanier RY. Generic assignments, strain histories and properties of pure cultures of cyanobacteria. Microbiology. 1979;111(1):1-61. doi:10.1099/00221287-111-1-1

24. MubarakAli D, Gopinath V, Rameshbabu N, Thajuddin N. Synthesis and characterization of CdS nanoparticles using C-phycoerythrin from the marine cyanobacteria. Mater Lett. 2012;74:8-11. doi:10.1016/j.matlet.2012.01.026

25. Nowruzi B, Khavari-Nejad R-A, Sivonen K, Kazemi B, Najafi F, Nejadsattari T. Identification and toxigenic potential of a Nostoc sp. Algae. 2012;27(4):303-313. doi:10.4490/algae.2012.27.4.303

26. Ehrenreich IM, Waterbury JB, Webb EA. Distribution and diversity of natural product genes in marine and freshwater cyanobacterial cultures and genomes. Appl Environ Microbiol. 2005;71(11):74017413. doi:10.1128/AEM.71.11.7401-7413.2005

27. Dembitsky V, Řezanka T. Metabolites produced by nitrogen-fixing Nostoc species. Folia Microbiol (Praha). 2005;50(5):363-391. doi:1 $0.1007 / \mathrm{bf02931419}$

28. Dittmann E, Neilan B, Börner T. Molecular biology of peptide and polyketide biosynthesis in cyanobacteria. Appl Microbiol Biotechnol. 2001;57(4):467-473. doi:10.1007/s002530100810

29. Salem OM, Hoballah E, Ghazi SM, Hanna SN. Antimicrobial activity of microalgal extracts with special emphasize on Nostoc sp. Life Sci J. 2014;11(12):752-758.

30. Bhalamurugan GL, Valerie O, Mark L. Valuable bioproducts obtained from microalgal biomass and their commercial applications: a review. Environ Eng Res. 2018;23(3):229-241. doi:10.4491/eer.2017.220

31. Yücer TD, Beyatlı Y, Pabuçcu K. The antiproliferative and antimicrobial effects of cultivated Anabaena circinalis Rabenhorts ex Bornet and Flahault and Nostoc entophytum Bornet and Flahault. Trop J Pharm Res. 2018;17(8):1571-1577. doi:10.4314/tjpr.v17i8.15

32. Soni B, Visavadiya NP, Dalwadi N, Madamwar D, Winder C, Khalil C. Purified C-phycoerythrin: safety studies in rats and protective role against permanganate-mediated fibroblast-DNA damage. $J \mathrm{Appl}$ Toxicol. 2010;30(6):542-550. doi:10.1002/jat.1524

33. Kalabegishvili T, Murusidze I, Kirkesali E, et al. Gold and silver nanoparticles in Spirulina platensis biomass for medical application. Ecol Chem Eng S. 2013;20(4):621-631. doi:10.2478/eces-2013-0043

34. Lengke MF, Fleet ME, Southam G. Biosynthesis of silver nanoparticles by filamentous cyanobacteria from a silver (I) nitrate complex. Langmuir. 2007;23(5):2694-2699. doi:10.1021/la0613124

35. Ali DM, Sasikala M, Gunasekaran M, Thajuddin N. Biosynthesis and characterization of silver nanoparticles using marine cyanobacterium, Oscillatoria willei NTDM01. Dig J Nanomater Biostruct. 2011;6 (2):385-390.

36. Sonker AS, Pathak J, Kannaujiya VK, Sinha RP. Characterization and in vitro antitumor, antibacterial and antifungal activities of green synthesized silver nanoparticles using cell extract of Nostoc sp. strain HKAR-2. Can J Biotechnol. 2017;1(1):26-37. doi:10.24870/cjb. 2017-000103
37. El-Naggar NE-A, Hussein MH, El-Sawah AA. Phycobiliproteinmediated synthesis of biogenic silver nanoparticles, characterization, in vitro and in vivo assessment of anticancer activities. Sci Rep. 2018;8(1):8925-8945. doi:10.1038/s41598-018-27276-6

38. Fabrega J, Luoma SN, Tyler CR, Galloway TS, Lead JR. Silver nanoparticles: behaviour and effects in the aquatic environment. Environ Int. 2011;37(2):517-531. doi:10.1016/j.envint.2010.10.012

39. Roychoudhury P, Gopal PK, Paul S, Pal R. Cyanobacteria assisted biosynthesis of silver nanoparticles - a potential antileukemic agent. $J$ Appl Phycol. 2016;28(6):3387-3394. doi:10.1007/s10811-016-0852-1

40. Mani AK, Seethalakshmi S, Gopal V. Evaluation of in-vitro anti-inflammatory activity of silver nanoparticles synthesised using piper nigrum extract. J Nanomed Nanotechnol. 2015;6(2):1-5. doi:10.4172/21577439.1000268

41. Agarwal H, Kumar SV, Rajeshkumar S. Antidiabetic effect of silver nanoparticles synthesized using lemongrass (Cymbopogon Citratus) through conventional heating and microwave irradiation approach. $J$ Microbiol Biotechnol Food Sci. 2018;7(4):1-6. doi:10.15414/jmbfs. 2018.7.4.371-376

42. Fathima JB, Pugazhendhi A, Oves M, Venis R. Synthesis of ecofriendly copper nanoparticles for augmentation of catalytic degradation of organic dyes. J Mol Liq. 2018;260:1-8. doi:10.1016/j. molliq.2018.03.033

43. Jahangirian H, Lemraski EG, Webster TJ, Rafiee-Moghaddam R, Abdollahi Y. A review of drug delivery systems based on nanotechnology and green chemistry: green nanomedicine. Int $J$ Nanomedicine. 2017;12:2957-2978. doi:10.2147/IJN.S127683

44. Moustafa MT. Removal of pathogenic bacteria from wastewater using silver nanoparticles synthesized by two fungal species. Water Sci. 2017;31(2):164-176. doi:10.1016/j.wsj.2017.11.001

45. Gokarneshan N, Velumani K. Application of nano silver particles on textile materials for improvement of antibacterial finishes. Global J Nanomed. 2017;2(3):1-4. doi:10.19080/GJN.2017.02.555586

46. Vijayaraghavan K, Nalini SK. Biotemplates in the green synthesis of silver nanoparticles. Biotechnol J. 2010;5(10):1098-1110. doi:10.1002/ biot. 201000167

47. Manivasagan P, Nam SY, Oh J. Marine microorganisms as potential biofactories for synthesis of metallic nanoparticles. Crit Rev Microbiol. 2016;42(6):1007-1019. doi:10.3109/1040841X.2015.113 7860

48. Varthamanan J. Anti cancer activity of silver nano particles biosynthesized using stingless bee propolis (Tetragonula iridipennis) of Tamilnadu. Asian J Biomed Pharm Sci. 2015;5(40):30-38. doi:10.15 272/ajbps.v4i40.654

49. Kathiravan V, Ravi S, Ashokkumar S. Synthesis of silver nanoparticles from Melia dubia leaf extract and their in vitro anticancer activity. Spectrochim Acta Part A. 2014;130:116-121. doi:10.1016/j. saa.2014.03.107

50. Netala VR, Bethu MS, Pushpalatha B, et al. Biogenesis of silver nanoparticles using endophytic fungus Pestalotiopsis microspora and evaluation of their antioxidant and anticancer activities. Int $J$ Nanomedicine. 2016;11:5683-5696. doi:10.2147/IJN.S112857

51. Bolch CJ, Orr PT, Jones GJ, Blackburn SI. Genetic, morphological, and toxicological variation among globally distributed strains of Nodularia (Cyanobacteria). J Phycol. 1999;35(2):339-355. doi:10.10 46/j.1529-8817.1999.3520339.x

52. Anagnostidis K, Komárek J. Modern approach to the classification system of cyanophytes. 3-Oscillatoriales. Archiv Für Hydrobiologie. 1988;327-472.

53. Singh SP, Rastogi RP, Häder D-P, Sinha RP. An improved method for genomic DNA extraction from cyanobacteria. World J Microbiol Biotechnol. 2011;27(5):1225-1230. doi:10.1007/ s11274-010-0571-8

54. Ahmed E, Hafez A, Ismail F, Elsonbaty M, Abbas H, Eldin RS. Biosynthesis of silver nanoparticles by Spirulina platensis and Nostoc sp. Glo Adv Res J Microbiol. 2015;4(4):36-49. 
55. Morsy FM, Nafady NA, Abd-Alla MH, Elhady DA. Green synthesis of silver nanoparticles by water soluble fraction of the extracellular polysaccharides/matrix of the cyanobacterium Nostoc commune and its application as a potent fungal surface sterilizing agent of seed crops. Univ $J$ Microbiol Res. 2014;2(2):36-43. doi:10.13189/ujmr.2014.020303

56. Vanlalveni C, Rajkumari K, Biswas A, Adhikari PP, Lalfakzuala R, Rokhum L. Green synthesis of silver nanoparticles using Nostoc linckia and its antimicrobial activity: a novel biological approach. BioNanoScience. 2018;8(2):624-631. doi:10.1007/s12668-018-0520-9

57. Karthik L, Kumar G, Kirthi AV, Rahuman A, Rao KB. Streptomyces sp. LK3 mediated synthesis of silver nanoparticles and its biomedical application. Bioprocess Biosyst Eng. 2014;37(2):261-267. doi:10.10 07/s00449-013-0994-3

58. Vanaja M, Annadurai G. Coleus aromaticus leaf extract mediated synthesis of silver nanoparticles and its bactericidal activity. Appl Nanosci. 2013;3(3):217-223. doi:10.1007/s13204-012-0121-9

59. Ibraheem I, Abd-Elaziz B, Saad W, Fathy W. Green biosynthesis of silver nanoparticles using marine Red Algae Acanthophora specifera and its antimicrobial activity. J Nanomed Nanotechnol. 2016;7(409):1-4.

60. Jeeva K, Thiyagarajan M, Elangovan V, Geetha N, Venkatachalam P. Caesalpinia coriaria leaf extracts mediated biosynthesis of metallic silver nanoparticles and their antibacterial activity against clinically isolated pathogens. Ind Crops Prod. 2014;52:714-720. doi:10.1016/j. indcrop.2013.11.037

61. El-Naggar NE-A, Mohamedin A, Hamza SS, Sherief A-D. Extracellular biofabrication, characterization, and antimicrobial efficacy of silver nanoparticles loaded on cotton fabrics using newly isolated Streptomyces sp. SSHH-1E. J Nanomater. 2016;2016:1-17. doi:10.1155/2016/3257359

62. Gole A, Dash C, Ramakrishnan V, et al. Pepsin- gold colloid conjugates: preparation, characterization, and enzymatic activity. Langmuir. 2001;17(5):1674-1679. doi:10.1021/la001164w

63. Sastry M, Ahmad A, Khan MI, Kumar R. Biosynthesis of metal nanoparticles using fungi and actinomycete. Curr Sci. 2003;85(2):162-170.
64. El-Batal A, Amin M, Shehata MM, Hallol MM. Synthesis of silver nanoparticles by Bacillus stearothermophilus using gamma radiation and their antimicrobial activity. World Appl Sci J. 2013;22(1):1-16. doi:10.5829/idosi.wasj.2013.22.01.2956

65. Vasantharaj S, Sathiyavimal S, Senthilkumar P, LewisOscar F, Pugazhendhi A. Biosynthesis of iron oxide nanoparticles using leaf extract of Ruellia tuberosa: antimicrobial properties and their applications in photocatalytic degradation. J Photochem Photobiol B. 2019;192:74-82. doi:10.1016/j.jphotobiol.2018.12.025

66. de Aragao AP, de Oliveira TM, Quelemes PV, et al. Green synthesis of silver nanoparticles using the seaweed Gracilaria birdiae and their antibacterial activity. Arabian J Chem. 2016;2016:1-7. doi:10.1016/j. arabjc.2016.04.014

67. Rashid MMO, Akhter KN, Chowdhury JA, Hossen F, Hussain MS, Hossain MT. Characterization of phytoconstituents and evaluation of antimicrobial activity of silver-extract nanoparticles synthesized from Momordica charantia fruit extract. BMC Complement Altern Med. 2017;17(1):336-344. doi:10.1186/s12906-017-1843-8

68. Martins AF, Follmann HD, Monteiro JP, et al. Polyelectrolyte complex containing silver nanoparticles with antitumor property on Caco2 colon cancer cells. Int J Biol Macromol. 2015;79:748-755. doi:10.1016/j.ijbiomac.2015.05.036

69. Song Y, Guan R, Lyu F, Kang T, Wu Y, Chen X. In vitro cytotoxicity of silver nanoparticles and zinc oxide nanoparticles to human epithelial colorectal adenocarcinoma (Caco-2) cells. Mutat Res. 2014;769:113-118. doi:10.1016/j.mrfmmm.2014.08.001

70. Satapathy SR, Mohapatra P, Preet R, et al. Silver-based nanoparticles induce apoptosis in human colon cancer cells mediated through p53. Nanomedicine. 2013;8(8):1307-1322. doi:10.2217/nnm.12.176

71. Böhmert L, Niemann B, Thünemann AF, Lampen A. Cytotoxicity of peptide-coated silver nanoparticles on the human intestinal cell line Caco-2. Arch Toxicol. 2012;86(7):1107-1115. doi:10.1007/s00204012-0840-4
International Journal of Nanomedicine

\section{Publish your work in this journal}

The International Journal of Nanomedicine is an international, peerreviewed journal focusing on the application of nanotechnology in diagnostics, therapeutics, and drug delivery systems throughout the biomedical field. This journal is indexed on PubMed Central, MedLine, CAS, SciSearch ${ }^{\circledR}$, Current Contents ${ }^{\mathbb{R}} /$ Clinical Medicine,

\section{Dovepress}

Journal Citation Reports/Science Edition, EMBase, Scopus and the Elsevier Bibliographic databases. The manuscript management system is completely online and includes a very quick and fair peer-review

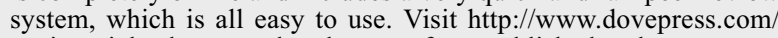
testimonials.php to read real quotes from published authors. 